\title{
REMOTE-SENSING STUDIES OF KVITØYJØKULEN, AN ICE CAP ON KVITØYA, NORTH-EAST SVALBARD
}

\author{
By Jonathan L. BAMBeR
}

(Mullard Space Science Laboratory, Department of Physics and Astronomy, University College London,

Holmbury St Mary, Dorking, Surrey RH5 6NT, England)

and Julian A. Dowdeswell

(Scott Polar Research Institute, University of Cambridge, Cambridge CB2 1ER, England)

\section{ABSTRACT}

Airborne $60 \mathrm{MHz}$ radio echo-sounding data were collected over $250 \mathrm{~km}$ of flight track from an ice cap (Kvitøyjøkulen) on Kvitøya in north-eastern Svalbard. These were combined with Landsat imagery to provide ice-surface and bed topographic information and inferences about the thermal and climatic conditions on the ice cap. Quantitative analysis of radio-echo strength measurements and the existence of offshore plumes of sediment-laden melt water indicate significant basal melting and a warmer thermal regime than would be expected from the geographical location of the ice cap. Analysis of the dielectric absorption of radio waves by the ice and data from a recently recovered ice core from a neighbouring ice cap (Austfonna) suggest considerable anthropogenic contamination of the precipitation falling on Kvitøya, most probably originating from Eurasia.

\section{INTRODUCTION}

Kvitøya is the most north-easterly island within the Svalbard archipelago, and is the island furthest from the relatively warm North Atlantic Drift, which flows along the west coast of Spitsbergen (Fig. 1). The ice cap on Kvitøya, Kvitøyjøkulen, therefore represents an end member to the suite of ice masses on Svalbard in terms of its relatively cold climate, low equilibrium-line altitude, and very high percentage of ice-covered island area (Liestøl, in press). For this reason, Kvitøyjøkulen was included in an airborne radio echo-sounding survey of the ice masses on Svalbard, undertaken during spring 1983 (Drewry and Liestøl, 1985; Dowdeswell and others, 1986; Dowdeswell, unpublished). The aims of this paper are: (i) to present information on the ice thickness, surface and bed topography of the ice cap; (ii) to examine echo-power measurements, which provide information on the bulk thermal regime and/or ice-impurity levels and the ice/bed interface; (iii) to compare echo-power data with those from other areas in Svalbard to help elucidate variations in thermal or basal conditions.

Perhaps because of its relatively harsh climate and inaccessibility, little was known about the glaciology or even the topography of Kvitøya until very recently. The island is infamous for the discovery in 1930 of the last camp of S.A. Andrée's 1897 balloon expedition to the North Pole; hence the name Andréeneset at its western end (Fig. 1). It was not until the availability of Landsat satellite imagery from the mid-1970s that surveyors at the Norsk Polarinstitutt were able to map the outline of Kvitøya with any

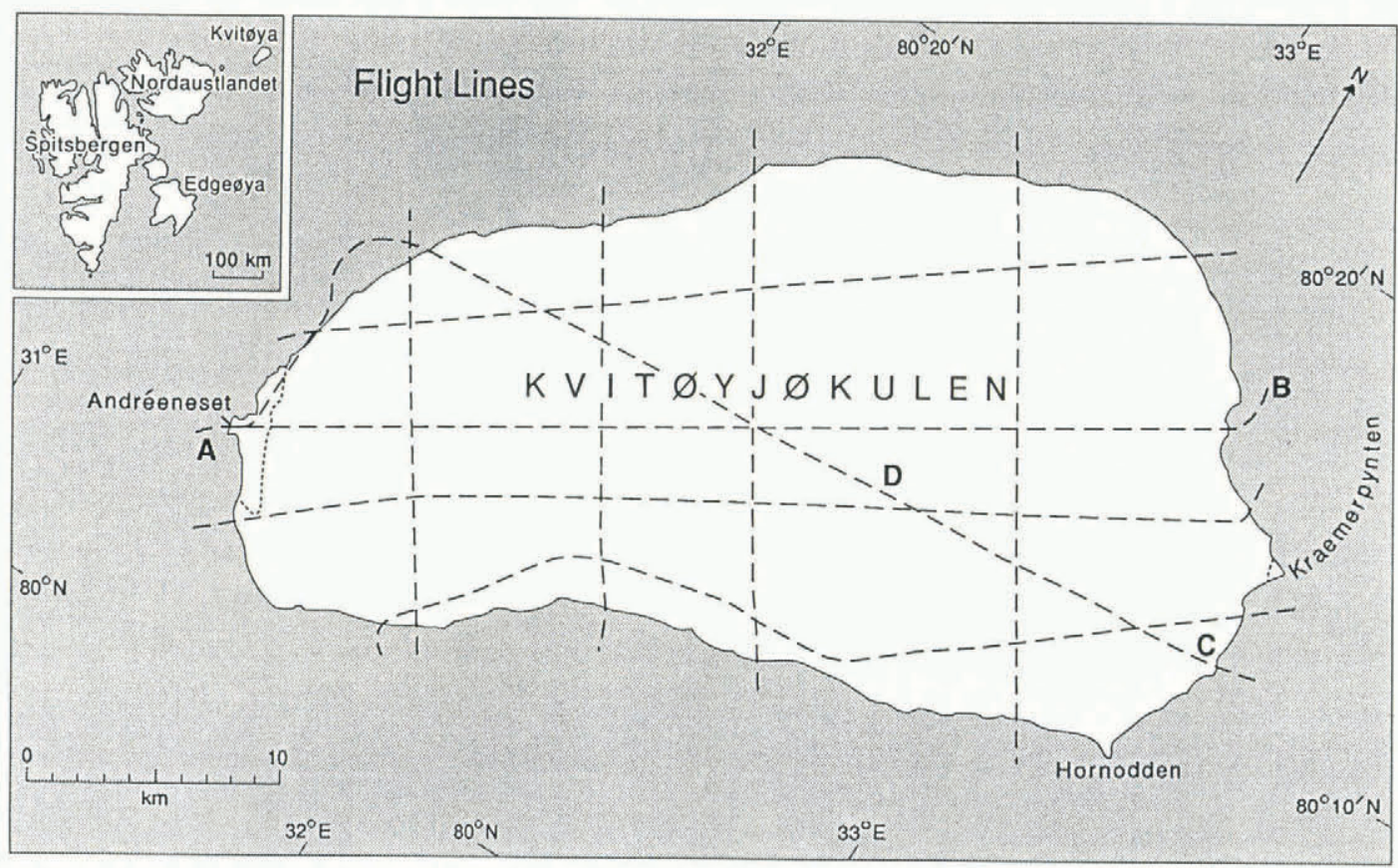

Fig. 1. The ice cap of Kvitoyjokulen on Kvitoya, with the location of radio echo-sounding flight lines shown. Flight lines $A-B$ and $C-D$ were analysed for surface-slope distributions (Fig. 3). The Svalbard archipelago is inset. 
accuracy and, more recently, vertical aerial photographs were obtained and the few areas of bare land fixed by satellite geoceiver. These data show Kvitøya has an area of $710 \mathrm{~km}^{2}$, of which $705 \mathrm{~km}^{2}$ is glacierized, forming the ice cap of Kvitøyjøkulen (Liestøl, in press). The ice cap ends in calving tide-water ice cliffs around $92 \%$ of its $115 \mathrm{~km}$ long margin (Fig. 1).

\section{DATA ACQUISITION AND METHODS}

Radio echo-sounding (RES) data were obtained using a SPRI MK IV sounder operating at a centre frequency of $60 \mathrm{MHz}$. The geometric mean of eight individual wave forms, each comprising 256 samples taken at $100 \mathrm{~ns}$ intervals, was recorded digitally. A detailed account of the digital recording system may be found in Gorman and Cooper (1987).

Data were also recorded in analogue "Z"-scope form using an oscillograph and heat-sensitive paper. The ice-surface elevation changes were tracked automatically, but for the weaker, noisier, and more intermittent bed echoes this was not possible. Instead, a power-differentiated continuous display was produced from the digital data and digitized manually. The errors in depth measurement incurred are negligible in comparison to the digital sampling length (equivalent to $8.4 \mathrm{~m}$ in ice, which defines the maximum resolution of an individual pulse).

Absolute elevations were calculated using terrain clearance from the radar sounder and a pressure altitude calibrated by overflying areas of open water. Interpolation between pulses enabled the relative surface elevation to be found to within $2 \mathrm{~m}$ (Dowdeswell, unpublished). Ice thicknesses were calculated using a mean value for the permittivity of ice of 3.17 (equivalent to an EM velocity of $168 \mathrm{~m} \mathrm{ss}^{-1}$ in ice).

Navigation was carried out using a combination of a Tactical Airborne Navigation System (TANS) and coastal crossing points. Due to the relatively uniform nature of the coastline, across-track errors were fairly large - up to $1 \mathrm{~km}$. Analysis of $32 \mathrm{flight}$-line crossing points over the ice cap produced a mean surface-elevation difference of $18.7 \mathrm{~m}$.

Calibration of the radio-echo logarithmic receiver was achieved by flying over a calm sea surface, with an assumed power-reflection coefficient of unity, at a constant terrain clearance of $600 \mathrm{~m}$. A variable attenuator with $10 \mathrm{~dB}$ steps placed in front of the receiver allowed the relationship between the digitally recorded power level and attenuation to be determined. The procedure was carried out at the start and the end of field work.
Landsat MSS images of Kvitøya were also acquired to provide: (i) a synoptic view of ice-surface elevations to complement the grid of RES data; (ii) data on the elevation of the snow line and areas of ice-surface melting; and (iii) information on the presence or otherwise of turbid, subglacially derived melt water around the ice-cap margins. MSS data in the form of computer-compatible tapes were obtained and analysed digitally on a GEMS image-processing system.

\section{RADIO ECHO-SOUNDING TOPOGRAPHIC RESULTS}

\section{Ice-surface and bed morphology}

The ice surface of Kvitøyjøkulen has been contoured at $50 \mathrm{~m}$ intervals. Landsat imagery was used to interpolate ice-surface contours between flight lines. The surface displays a relatively simple topography comprising two ice domes (Fig. 2). The eastern dome rises to a maximum measured elevation of $373 \mathrm{~m}$ a.s.1. The western dome is smaller in extent and altitude rising to a maximum recorded elevation of $324 \mathrm{~m}$ a.s.l. The true summits of these domes were not overflown and are likely to be $10-20 \mathrm{~m}$ higher than the maximum recorded values.

The frequency distribution of ice-surface slopes has been calculated for two transects along flow lines with a total length of about $50 \mathrm{~km}$ (Figs 1 and 3). Due to edge effects, slope angles are somewhat higher than typical values from the larger ice caps on Nordaustlandet to the west (Fig. 1) (Dowdeswell and McIntyre, 1986). On Kvitøya only $60 \%$ of slopes are less than $1^{\circ}$ and $71 \%$ are less than $1.5^{\circ}$.

Bed topography beneath Kvitøyjøkulen is also relatively simple, with slopes typically on the order of $0.7^{\circ}$ or less (Fig. 4). Near the ice-cap margins, bed elevations drop below sea-level with a minimum observed value of $115 \mathrm{~m}$ b.s.l. Elevations gradually increase inland with a maximum observed value of $72 \mathrm{~m}$ a.s.l. In substantial inland areas of the ice cap, however, no bed echoes were received due to high levels of absorption and internal scattering. These areas are indicated by dashed lines on the contour diagrams (Figs 4 and 5). Measured ice thicknesses ranged between approximately 100 and $300 \mathrm{~m}$ (Fig. 5).

Driving stresses were calculated along flight lines that follow ice-flow lines. Slopes were averaged over $4 \mathrm{~km}$ (approximately ten times the ice thickness). Where no bed elevations were present, usually in the central region, values were interpolated between data on either side of the gap. This introduces an error of up to $20 \%$ in the ice-thickness data but allows the general trends in driving stresses to be seen. Although the bedrock elevation has not been averaged, introducing a false high-frequency component, the overall

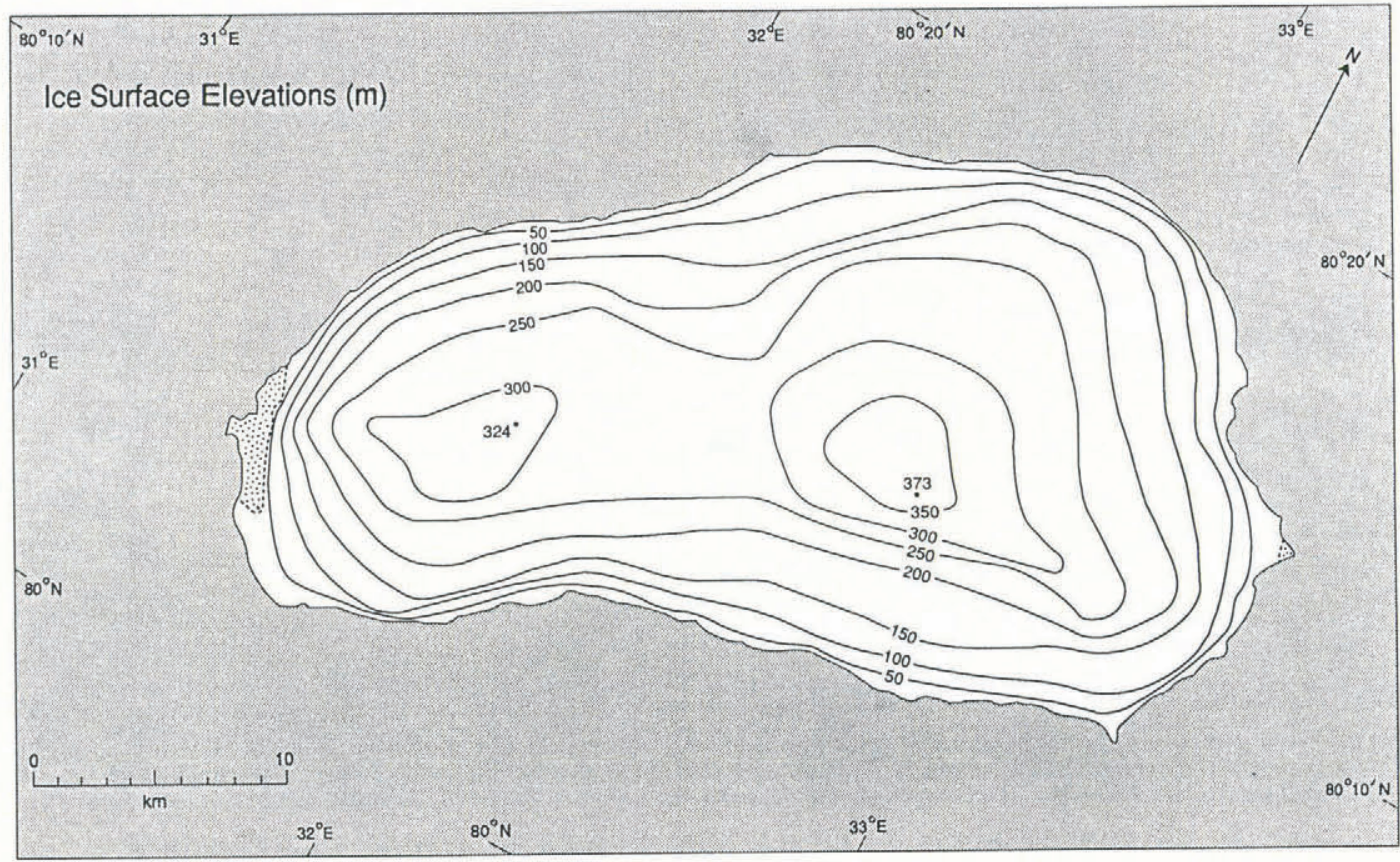

Fig. 2. Ice-surface contour map of Kvitøyjøkulen. 
pattern is clear. The driving stresses show values increasing to a maximum towards the ice-cap margins (Fig. 6a) with the lowest values being found in the regions of the two domes, as expected.

\section{Theoretical long profiles}

Theoretical ice-cap long profiles were calculated using the equation:

$$
h_{\mathrm{S}}=3.35(L-x)^{0.5}
$$

(Paterson, 1981) where $h_{\mathrm{S}}$ is surface elevation, $L$ is the ice-mass half-width, and $x$ is distance from the centre. The use of this equation assumes a flat, rigid bed with no basal sliding and no calving. Mass balance, temperature, and other factors influencing ice velocity are all assumed to be constant. Despite these fairly restrictive assumptions, in the absence of adequate boundary conditions, Equation (1) provides a qualitative indication of the stability of an ice cap (Paterson, 1981). Figure 6b is a comparison of the theoretical and measured profile for the section of flight

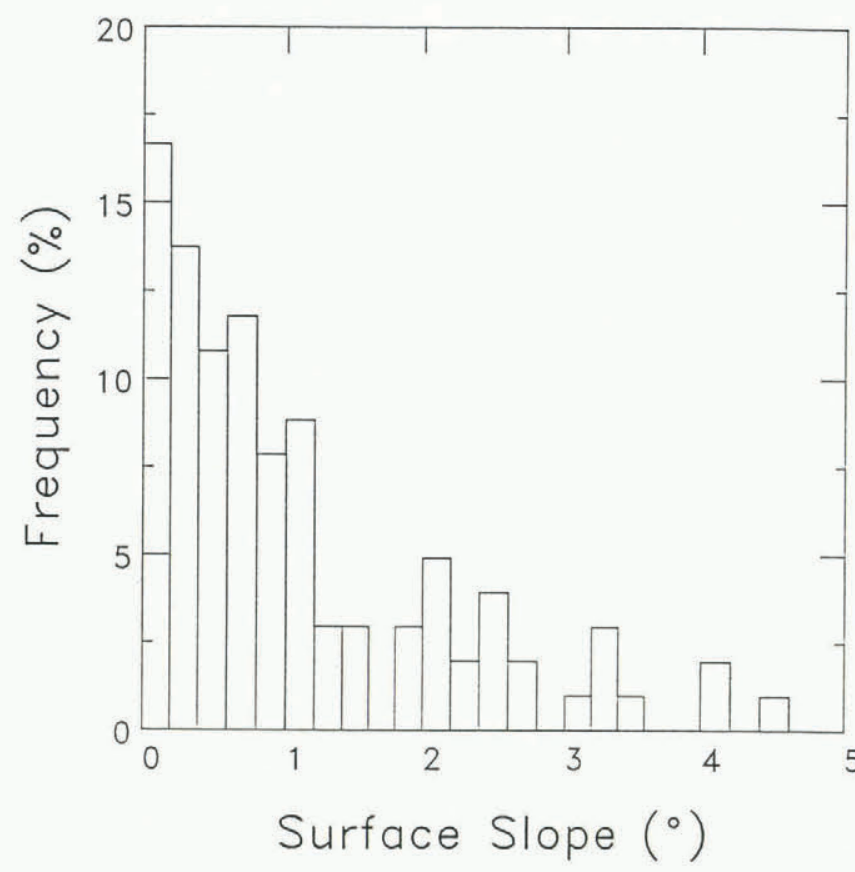

Fig. 3. Histogram of ice-surface slopes along the transects $A-B$ and $C-D$ (Fig. 1). line $\mathrm{A}-\mathrm{B}$ in Figure 1. It can be seen that for the western dome the theoretical profile is significantly lower than the observed profile. Combined with a relatively high driving stress in this area (Fig. 6a), this suggests that the bed may be frozen here. For the eastern dome there is good agreement between the two profiles.

Most of the other flight lines do not follow flow lines and therefore cannot be used for this analysis but those that do showed similar agreement to that indicated in Figure $6 \mathrm{~b}$.

The distribution of driving stresses and long profiles has a similar pattern to those of a number of drainage basins on Austfonna, Nordaustlandet (Dowdeswell, 1986). On Austfonna, three distinct groups of drainage basin were identified on the basis of their long profile and driving stresses. Basins with low driving stresses and surface profiles (relative to theoretical profiles derived from Equation (1)) were associated with observed surge activity, whereas none of those with high driving stresses and surface profiles had been observed to undergo surging. It is inferred, therefore, by comparison with the behaviour of the neighbouring ice caps on Nordaustlandet, that the driving-stress distribution and surface profiles on Kvitøyjøkulen do not indicate that surges have occurred in the recent past.

\section{Landsat imagery and subglacial water}

Beyond the margins of Austfonna, the presence of turbid plumes of subglacially derived melt water has been used to infer the existence of basal melting (Dowdeswell and Drewry, 1989). Digital enhancement of sea-surface pixels from Landsat CCTs shows similar surface sediment plumes emanating from point sources in the terminal ice cliffs of Kvitøyjøkulen. Water-turbidity measurements off the coast of Nordaustlandet confirm that features similar to those illustrated are a result of sediment-laden waters (Dowdeswell and Drewry, 1989). Although cloud obscures parts of the coast of Kvitøya, these plumes appear to occur at intervals around most of the ice cap (Fig. 7). These turbid melt waters come to the surface as they leave the confines of the ice cap because they are generally less dense than the ocean waters into which they flow. Their sediment content must come from the ice/bed interface, because there are no rock outcrops to provide a source of supraglacial debris. The presence of point sources for the sediment plumes also indicates that significant subglacial channels are formed and that, despite its location, the ice cap possesses significant areas of basal melting.

\section{Echo-strength measurements}

Measurement of the returned signal strength from the ice/substrate interface can provide information on both the

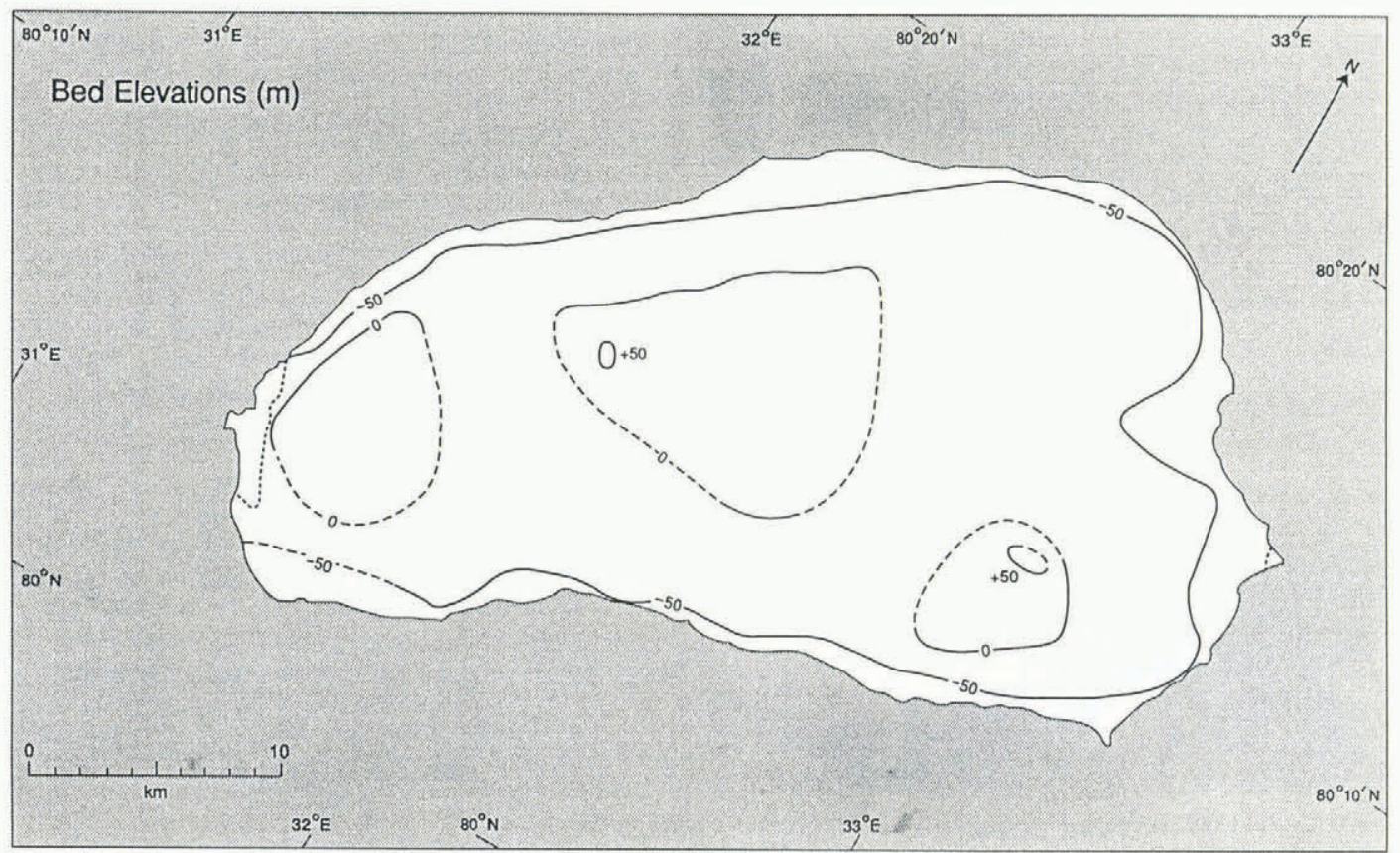

Fig. 4. Bed topography of Kvitøya deduced from radio echo-sounding data. Dashed lines represent regions of interpolated contours due to poor radio-echo returns from these areas. 


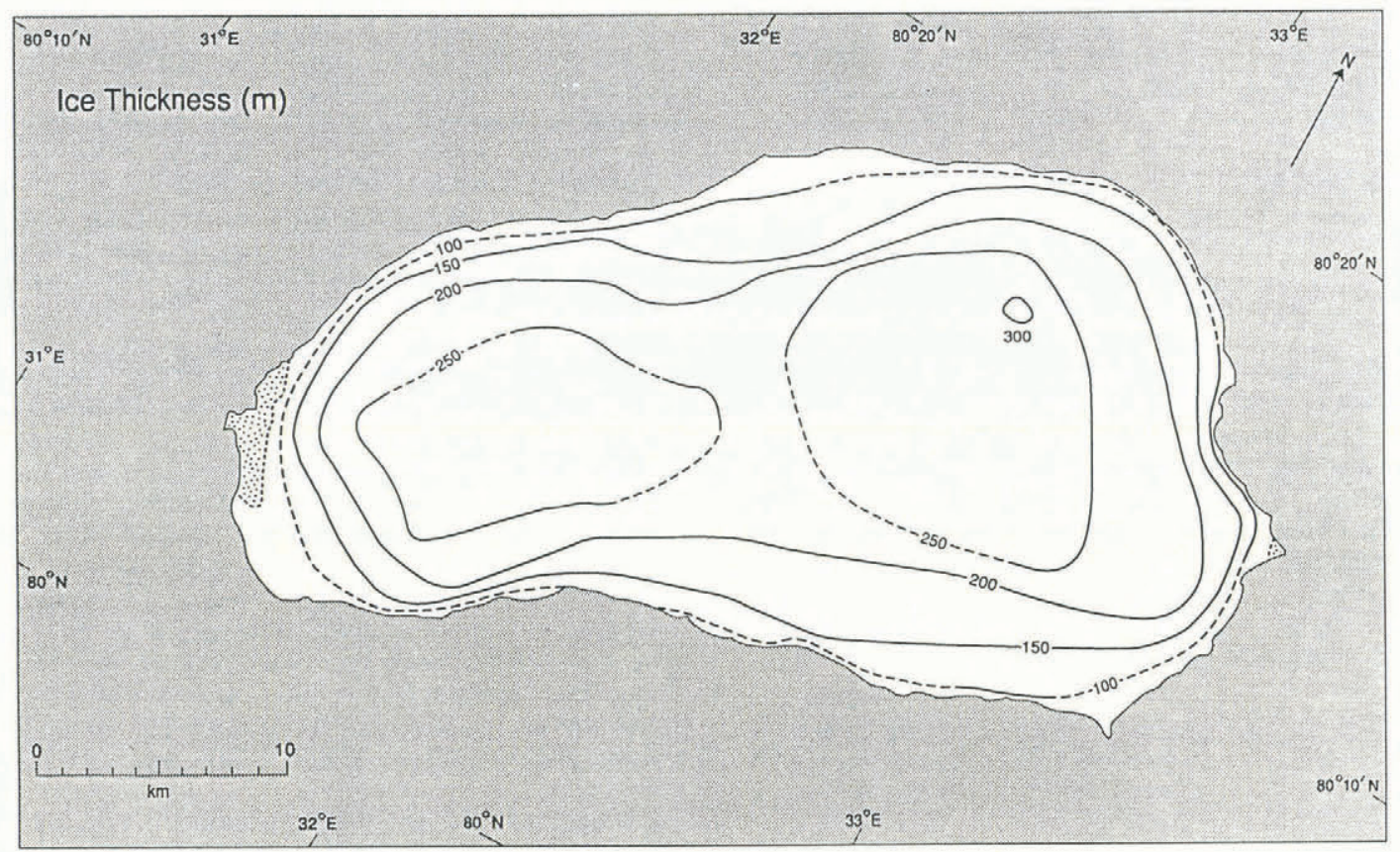

Fig. 5. Ice-thickness contour map for Kvitoyjokulen deduced from radio echo-sounding data. Dashed lines represent regions of interpolated contours due to poor radio-echo returns from these areas.
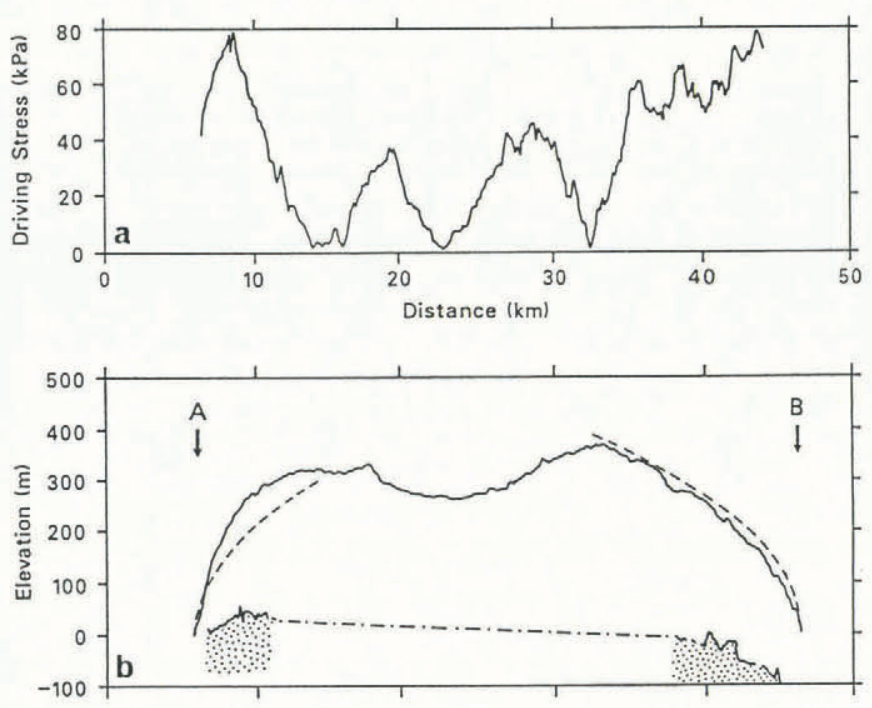

Fig. 6.a. Driving stresses along the flow line $A-B$ in Figure 1. Ice-surface slopes were averaged over $4 \mathrm{~km}$ (approximately 10-15 times the ice thickness). b. Observed (solid line) and theoretical (dashed line) ice-surface profile along a section of the flight line in Figure 1.

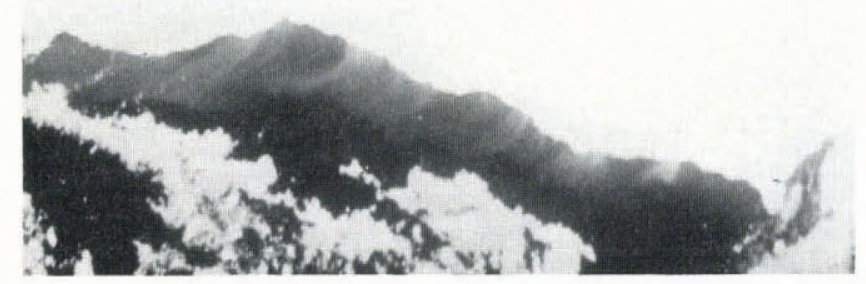

Fig. 7. Plumes of suspended sediment exiting from the subglacial drainage system of Kvitoyjokulen - digitally enhanced Landsat MSS bands 4, 5, and 7 acquired on 21 July 1979. nature of the interface and the bulk properties of the ice overlying it. Two parameters of interest can be derived from the returned echo strength. The first is the mean dielectric absorption, $\bar{B}$ (in $\mathrm{dB} \mathrm{m}^{-1}$ ). This is related to the real part of the high-frequency conductivity of the ice, $\sigma^{\prime}$, by the equation:

$$
\bar{B} \approx \frac{8.686 \sigma^{\prime}}{2 c \varepsilon_{0}\left(\varepsilon^{\prime}\right)^{\frac{1}{2}}}
$$

where $c$ is the velocity of light in vacuo, $\varepsilon_{0}$ is the permittivity of free space, and $\varepsilon^{\prime}$ is the real part of the relative permittivity of ice. The absorption is directly proportional to $\sigma^{\prime}$, and is usually influenced primarily by the ice temperature, through an Arrhenius-type equation. It is also, however, strongly influenced by the presence of impurities (Gross and others, 1978; Moore and others, 1989) and to a lesser extent by crystal-fabric and density variations.

The second parameter of interest is the powerreflection coefficient (PRC) of the ice/bed interface. This is determined from the radar equation which, in logarithmic form, can be expressed as:

$$
\begin{aligned}
10 \log \frac{P_{\mathrm{r}}}{P_{\mathrm{t}}} & =20 \log \frac{G \lambda_{0}}{8 \pi\left(H+z /\left(\varepsilon^{\prime}\right)^{\frac{1}{2}}\right)}+ \\
& +10 \log R-2 B(z) z-10 \log L
\end{aligned}
$$

where $P_{\mathrm{r}}$ and $P_{\mathrm{t}}$ are the received and transmitted power, respectively, $G$ is the antenna gain, $\lambda_{0}$ is the free-space wavelength, $H$ is the terrain clearance, $z$ is the ice thickness, $R$ is the power-reflection coefficient, $B(z)$ is the dielectric absorption in $\mathrm{dB} \mathrm{m}^{-1}$, and $L$ is antenna mismatch and cable losses. To obtain $R$, this equation requires a knowledge of the system parameters $\left(P_{\mathrm{t}}, G\right.$, and $\left.L\right)$. However, from the calibration graph for the receiver, it is possible to eliminate these constants by using the intercept (i.e. when the attenuation $=0$ ) to fix the value of the attenuation calculated from the radio echo-sounding data. The PRC (in $\mathrm{dB}$, i.e. $\mathrm{PRC}=10 \log R$ ) is then given as:

$$
\mathrm{PRC}=m(D+C)-20 \log \left(\frac{\lambda_{0}}{8 \pi(H+z / n)}\right)+2 B(z) z
$$

where $m$ is the gradient of the calibration graph, $C$ is a constant determined by the intercept and the geometrical 
spreading term for the calibration flight, $D$ is the digital value of signal strength, and $n$ is the refractive index $=\left(\varepsilon^{\prime}\right)^{\frac{1}{2}}$.

The PRC is dependent on the dielectric properties of the substrate and will vary according to the rock type (Bamber, unpublished). It is also very sensitive to the presence of water (Bamber, unpublished) which has a relative permittivity of between 10 and 20 times that of most rocks (Parkhomenko, 1967) and can also have a much higher conductivity than dry rock (Collins and Young, 1981). Consequently, even relatively small quantities of water at the bed can increase PRCs by $10 \mathrm{~dB}$ or more. An additional factor that influences the value of PRC is the metre-scale roughness of the bed. This can reduce the returned power by up to $15 \mathrm{~dB}$ (Neal, unpublished).

\section{Echo-strength results}

Absorption values

The only unknowns in Equation (4) are the PRC and $B(z)$. If the geometrical spreading term is removed, these represent the total attenuation of the radar wave (due to absorption and reflection losses):

$$
\text { Attenuation }=2 \bar{B} z-\text { PRC } .
$$

Hence, if the total attenuation is plotted against ice thickness for a given ice mass, the gradient of the plot is $2 \bar{B}$ (where the overbar denotes the mean value integrated over the total ice thickness) and the intercept is the PRC (Fig. 8). This assumes that the data are statistically

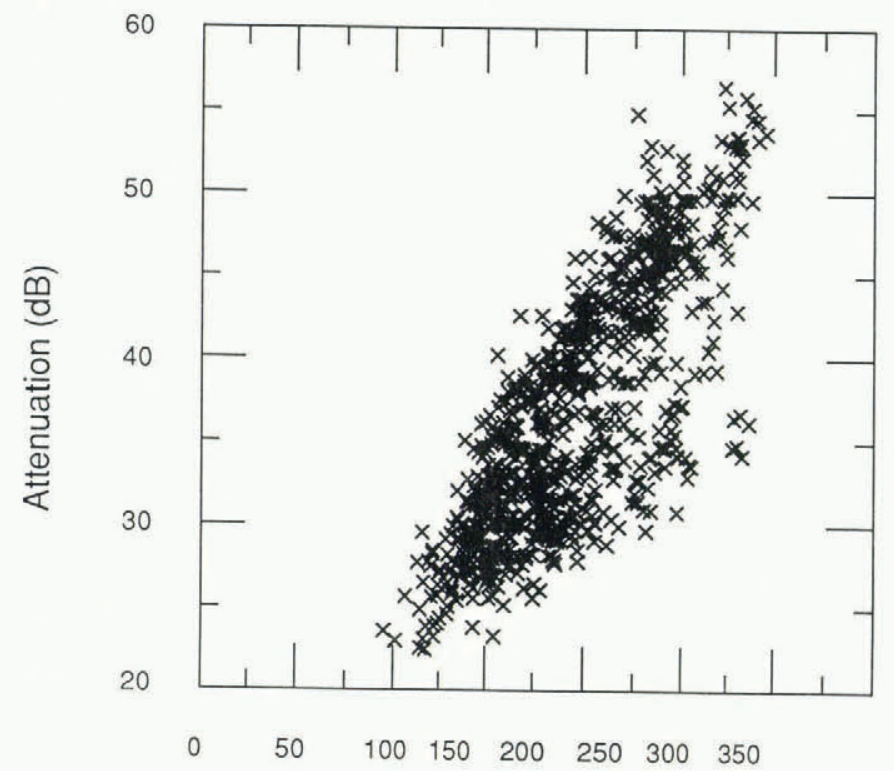

Ice thickness (m)

Fig. 8. Scatter plot of ice thickness versus attenuation for all the valid data over Kvitoya.

Stationary over the area being investigated, that is, that both $\bar{B}$ and the bed PRC are invariant. This is clearly an approximation as the mean temperature would be expected to vary with ice thickness and elevation. The justification for this approximation was assessed by the spread in points about the fitted regression line. Pearson's product-moment correlation coefficient was used to quantify this. Data with a correlation of $<0.8$ were considered to possess an unsatisfactory linear fit.

It would be expected that, if the primary influence on absorption in Svalbard is temperature, then Kvitøyjøkulen should, due to its location at the north-eastern extremity of the archipelago, have the lowest value. It might also be expected that there would be some variation with altitude. A number of different methods of grouping the data were investigated to establish whether there were any areal variations in absorption. Data from Austfonna, Nordaustlandet (the largest ice cap in the archipelago), were found to vary monotonically with elevation, and lower values (presumably indicating lower temperatures) were found at higher elevations (Bamber, unpublished). A similar analysis was undertaken for Kvitøya but, partly due to the less extensive coverage, no significant relationship was found. The absorption values were also separated into two groups divided by the approximate elevation of the equilibrium line (Liestøl, in press) but again no improvement in the correlation coefficients was obtained. Analysis of the whole data set gave a mean $\bar{B}$ of $7.48 \pm$ $0.2 \mathrm{~dB} / 100 \mathrm{~m}$ for 787 points with a correlation coefficient of 0.83 (Fig. 8).

There is a change in rock type from mainly granitic migmatites in the west of Kvitøya to quartz-diorite in the east, although the location of the geological boundary is not known (Lauritzen and Ohta, 1984). Examination of PRC data indicates a discontinuity of approximately $8 \mathrm{~dB}$ between values lying either side of a line running from lat. $80^{\circ} 13^{\prime} \mathrm{N}$., long. $31^{\circ} 54^{\prime} \mathrm{E}$. to lat. $80^{\circ} 09^{\prime} \mathrm{N}$., long. $32^{\circ}$ $26^{\prime}$ E. Separating the RES data along this line produces a considerable improvement in the value of the correlation coefficient for each group. The western and eastern parts gave, respectively, a mean absorption of $8.05 \pm 0.2$ and $7.49 \pm 0.2 \mathrm{~dB} / 100 \mathrm{~m}$ with correlation coefficients of 0.90 and 0.89 . These absorption values are equivalent to conductivities of 88 and $81 \mu \mathrm{S} \mathrm{m}^{-1}$, respectively, and are considerably higher than values obtained elsewhere in Svalbard (Bamber, 1989, unpublished). These range from approximately $4.5 \mathrm{~dB} / 100 \mathrm{~m}$ in western Spitsbergen to a maximum of $5.4 \mathrm{~dB} / 100 \mathrm{~m}$ on Austfonna, the largest ice cap in the archipelago (Fig. 9).

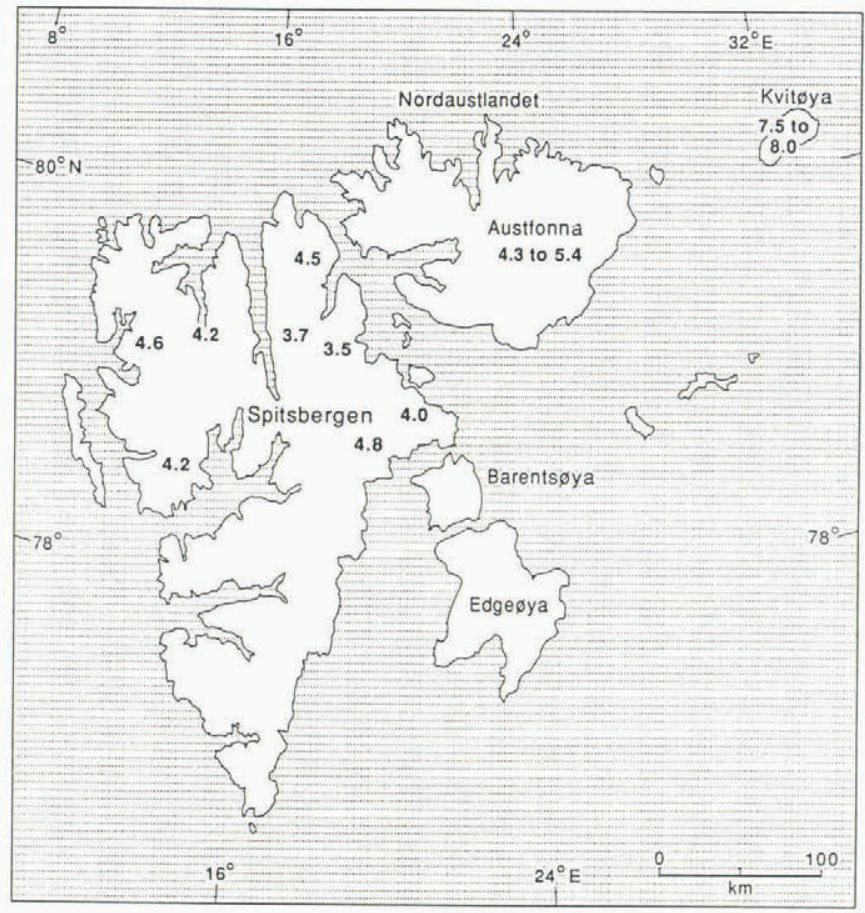

Fig. 9. Representative selection of mean radio-wave absorption values $(\mathrm{dB} / 100 \mathrm{~m})$ in Svalbard, indicating the regional pattern.

\section{Power-reflection coefficients}

The greatest errors involved in calculating the PRCs are in the estimation of $\bar{B}$. Experimental random errors are about $\pm 2.4 \mathrm{~dB}$, while errors from $\bar{B}$ are of the order of $\pm 2 \mathrm{~dB} / 100 \mathrm{~m}$ and can introduce an uncertainty of between 2 and $7 \mathrm{~dB}$ depending on ice thickness. Using the values of $B$ obtained in the previous section produced some unrealistically high values of PRC (including one or two positive values). A possible explanation for the apparent unsuitability of the calculated values will be given in the next section. Using lower values (more typical of the rest of Svalbard) still produced relatively high PRCs for Kvitøya, ranging between -5 and $-25 \mathrm{~dB}$.

A distinct geographical trend was observed for the PRC data (Fig. 10) for the Svalbard archipelago. The highest values $(-8$ to $-15 \mathrm{~dB})$ were found in western Spitsbergen and are believed to be associated with the presence of significant quantities of water at the glacier bed (Bamber, 1989, unpublished). Relatively low values ( -30 to $-40 \mathrm{~dB})$ were calculated for parts of the high-plateau ice 


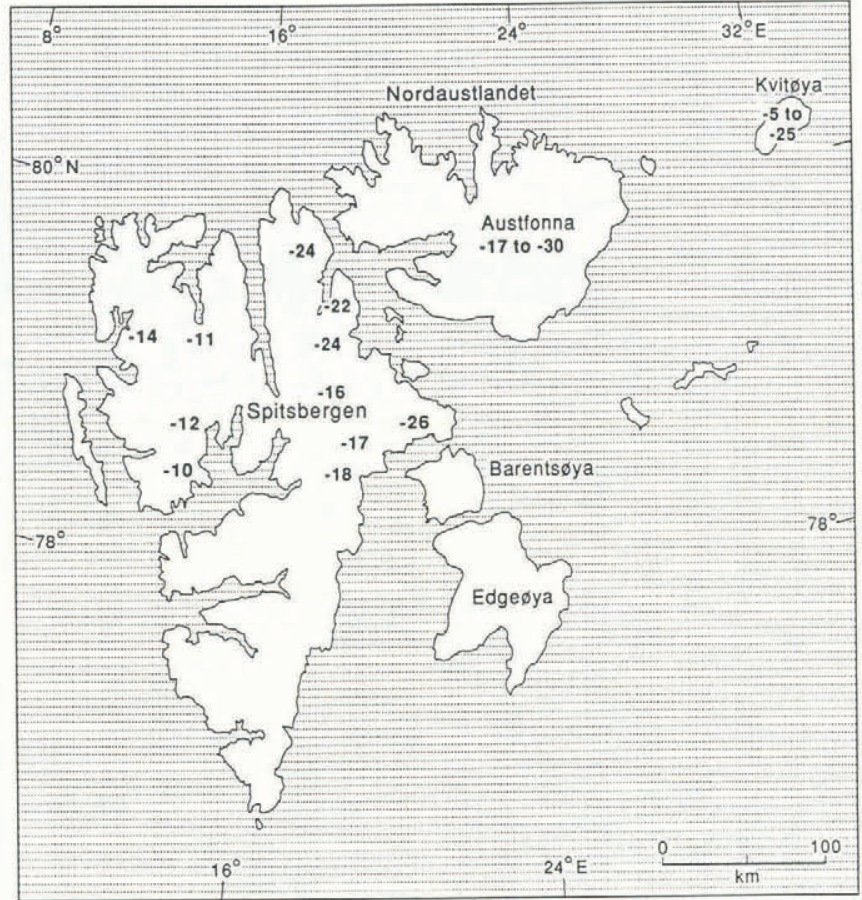

Fig. 10. Representative selection of mean bed-power reflection coefficients $(d B)$ in Svalbard, indicating the regional pattern.

caps in north-east Spitsbergen and were suggested to be due to a frozen bed most probably overlain by a debris-rich layer of ice (Bamber, 1989). Austfonna was found to have intermediate values (between -17 and $-30 \mathrm{~dB}$ ) but, as for the ice masses in Spitsbergen, there was a proportionality between PRCs and mean absorption values. Intuitively, this seems reasonable as high $\bar{B}$ values suggest higher temperatures and hence a greater presence of basal water.

\section{DISCUSSION}

The pattern of absorption values is shown in Figure 10. Although there is a less obvious trend in comparison to the PRCs, it is interesting to note that the two theoretically coldest ice masses (on the grounds of location and limited temperature data) in the archipelago, Austfonna and Kvitøyjøkulen, possess the highest absorption values. In addition, those from Kvitøya are approximately $40 \%$ higher than the highest value from Austfonna. If it were only temperature regulating absorption, then the bulk ice temperature for Kvitøya should be about $5^{\circ} \mathrm{C}$ warmer than for the warmest ice on Austfonna. This is unlikely as Kvitøya is in the coldest part of the Svalbard archipelago; there is a maximum elevation difference between them of $200 \mathrm{~m}$ and Landsat data suggest that both ice caps possess significant basal melting (Fig. 7). It is clear that another factor is having a strong influence on the dielectric properties of the ice. Factors, other than temperature, that can influence dielectric absorption include crystal fabric, density, the presence of water (linked to temperature), and impurity content (Glen and Paren, 1975). Assuming sensible physical limits for the variations in these parameters, the only factor that can produce such a marked increase in absorption is an increase in the impurity content.

Shallow snow samples have been collected from a number of different sites in Svalbard and showed a two- to three-fold increase in $\mathrm{H}^{+}$concentration between Spitsbergen and Austfonna (Semb and others, 1984). The highest value observed was obtained from near the summit of Austfonna and is equivalent to a $\mathrm{pH}$ of 4.53. It implies strongly acidified precipitation that is most likely of an anthropogenic origin. It has been shown that the wintertime air circulation in the Arctic originates from Eurasia and travels over Siberia, across the Arctic Ocean, approaching Svalbard from the east (Rahn, 1982). In summer, however, due to the retreat of the Arctic Front to higher latitudes, the air masses of ten come from the Atlantic and Iceland, and approach Svalbard from the west (Barrie, 1986).
Furthermore, studies of air pollution in the Arctic (Rahn and others, 1980) indicate much higher $\mathrm{SO}_{2}$ levels in the winter (December-March). There may be, therefore, an east/west gradient in impurity concentration in the precipitation over Svalbard. The ice mass lying at the extreme of this gradient is Kvitøyjøkulen. The ice cap is of sufficient altitude to cause substantial precipitation and moisture loss from approaching easterly air masses (Mason, 1971). The winter air stream will then pass over Austfonna and finally Spitsbergen. In summer, it is suggested that the majority of moisture is removed in traversing Spitsbergen from the west and little falls over Kvitøya.

A second factor that may enhance the proposed impurity gradient is melt-water percolation. It has been suggested that the existence of water at grain boundaries in temperate glaciers can remove the bulk of the impurities from the ice (Glen and others, 1977). On theoretical grounds, it has also been suggested that acids reside at grain boundaries (Wolff and Paren, 1984). Preliminary results from scanning electron microscopy of natural ice samples support this hypothesis (Wolff and Mulvaney, unpublished). The greater amounts of surface melt water present in Spitsbergen due to higher summer temperatures in the west of the archipelago would consequently produce more "impurity flushing" than on Austfonna or Kvitøya (which would presumably be least affected by this process).

It is important to consider the time-scale over which high levels of impurities (specifically acids) have been affecting the Arctic. Results from an ice core taken from Dye 3, Greenland, suggest that significant increases have taken place over approximately the last 100 years (Neftel and others, 1985). The accumulation rate on the summit of Austfonna is on the order of $0.4-0.5 \mathrm{~m} /$ year (Dowdeswell and Drewry, 1989). The order of magnitude of the time-scale and accumulation rate are strongly supported by data obtained from a Soviet ice core taken from the summit of Austfonna which displays a minimum $\mathrm{pH}$ at the surface of $5.2-5.3$, steadily increasing to a fairly constant value of about 5.6 at a depth of $80-100 \mathrm{~m}$ (paper in preparation by V.S. Zagarodnov and S.M. Arkhipov).

The equilibrium line on Kvitøya lies at an elevation of about $200 \mathrm{~m}$ a.s.1. (Liestøl, in press). Analysis of digital Landsat imagery confirms this value. The majority of ice below this level will be older than 100 years and consequently relatively "clean". Hence, the impure ice layer will form a "cap" lying over an almost flat layer of relatively pure ice. This lower layer, being reasonably uniform in thickness, would not be detected by plotting ice thickness against absorption and might explain why using the calculated values of $B$ gave unrealistically high PRCs. If a different model is used with a low-loss bottom layer of approximately $200 \mathrm{~m}$ thickness, then more realistic PRCs are obtained.

Let us assume that the increase in absorption on Kvitøya relative to the values on Nordaustlandet is due solely to an increase in $\mathrm{H}^{+}$. Using an empirically derived relationship between conductivity and $\mathrm{H}^{+}$(Moore and others, 1989 ), it is then possible to estimate $\delta \mathrm{H}^{+}$. The relationship is, however, temperature-dependent and the uncertainty in the temperature profile and the dependence means that the calculated value is only an "order-of-magnitude" estimate. The difference in absorption between the two ice masses is about $3 \mathrm{~dB} / 100 \mathrm{~m}$. This implies a difference in conductivity of $33 \mu \mathrm{S} \mathrm{m}^{-1}$ which, in turn, indicates a $\delta \mathrm{H}^{+}$of $13 \pm 6 \mu \mathrm{mol}$. This suggests more than a doubling in the acidity, which seems unlikely. If, however, the mean ice temperature for Kvitøya is higher than that for Nordaustlandet, then this would have the dual effect of increasing the influence of impurities and the intrinsic conductivity of the ice. It is unlikely that the ice from Kvitøya would contain a much greater concentration of sea salts compared with Nordaustlandet as the surface elevations are not too dissimilar and the sea-ice cover is greatest in extent both temporally and spatially in the extreme north-east.

\section{CONCLUSIONS}

The morphology of Kvitøya suggests a relatively stable ice cap with simple ice-surface and bed topography. The 
existence of debris-rich plumes of melt water offshore implies that there are areas of basal melting beneath the ice cap. Furthermore, significant areas of the bed are below sea-level, and any advance of the ice-cap margins would be over potentially deformable glaciomarine sediments. Echo-strength measurements have indicated an anomolously high radio-wave absorption relative to other ice masses sounded in Svalbard. It is believed that this is due to a higher level of anthropogenic impurities in the snow on Kvitøya than elsewhere in the archipelago and to a lower amount of melt-water percolation. This is associated with winter air circulation supplying polluted air from Eurasia. This hypothesis could be easily tested with an ice core or, less satisfactorily, from shallow snow measurements.

\section{ACKNOWLEDGEMENTS}

The data on which this work is based were collected as part of a collaborative project between the Scott Polar Research Institute, University of Cambridge, and the Norsk Polarinstitutt, Oslo. Funding came from U.K. NERC Research Grant GR3/4663 to Drs J.A. Dowdeswell and D.J. Drewry. The authors would like to thank Dr D.J. Drewry for his advice and comments.

\section{REFERENCES}

Bamber, J.L. 1989. Ice/bed interface and englacial properties of Svalbard ice masses deduced from airborne radio echosounding data. J. Glaciol., 35(119), 30-37.

Bamber, J.L. Unpublished. Radio echo sounding studies of Svalbard glaciers. (Ph.D. thesis, University of Cambridge, 1987.)

Barrie, L.A. 1986. Arctic air pollution: an overview of current knowledge. Atmos. Environ., 20(4), 643-663.

Collins, D.N. and G.J. Young. 1981. Meltwater hydrology and hydrochemistry in snow- and ice-covered mountain catchments. Nord. Hydrol., 12(4-5), 319-334.

Dowdeswell, J.A. 1986. Drainage-basin characteristics of Nordaustlandet ice caps, Svalbard. J. Glaciol., 32(110), 31-38.

Dowdeswell, J.A. Unpublished, Remote sensing studies of Svalbard glaciers. (Ph.D. thesis, University of Cambridge, 1984.)

Dowdeswell, J.A. and D.J. Drewry. 1989. The dynamics of Austfonna, Nordaustlandet, Svalbard: surface velocities, mass balance, and subglacial melt water. Ann. Glaciol., $12,37-45$.

Dowdeswell, J.A. and N.F. McIntyre. 1986. The saturation of LANDSAT MSS detectors over large ice masses. Int. J. Remote Sensing, 7(1), 151-164.

Dowdeswell, J.A., D.J. Drewry, A.P.R. Cooper, M.R Gorman, O. Liestøl, and O. Orheim. 1986. Digital mapping of the Nordaustlandet ice caps from airborne geophysical investigations. Ann. Glaciol., 8, 51-58.
Drewry, D.J. and O. Liestøl. 1985. Glaciological investigations of surging ice caps in Nordaustlandet, Svalbard, 1983. Polar Rec., 22(139), 359-378.

Glen, J.W. and J.G. Paren. 1975. The electrical properties of snow and ice. J. Glaciol., 15(73), 15-38.

Glen, J.W., D.R. Homer, and J.G. Paren. 1977. Water at grain boundaries: its role in the purification of temperate glacier ice. International Association of Hydrological Sciences Publication 118 (Symposium at Grenoble 1975 Isotopes and Impurities in Snow and Ice), 263-271.

Gorman, M.R. and A.P.R. Cooper. 1987. A digital radio echo-sounding and navigation recording system. Ann. Glaciol., 9, 81-84.

Gross, G.W., I.C. Hayslip, and R.N. Hoy. 1978. Electrical conductivity and relaxation in ice crystals with known impurity content. J. Glaciol., 21(85), 143-160.

Lauritzen, Ø. and Y. Ohta. 1984. Geological map of Svalbard 1:500,000. Sheet 4G. Nordaustlandet. Nor. Polarinst. Skr. 154 D.

Liestøl, O. In press. Glaciers of Svalbard, Norway. U.S Geol. Surv. Prof. Pap. 1386.

Mason, B.J. 1971. The physics of clouds. Second edition. Oxford, Clarendon Press.

Moore, J.C., R. Mulvaney, and J.G. Paren. 1989. Dielectric stratigraphy of ice: a new technique for determining total ion concentrations in polar ice cores. Geophys. Res. Lett., 16(10), 1177-1180.

Neal, C.S. Unpublished. Radio echo sounding studies of the Ross Ice Shelf. (Ph.D. thesis, University of Cambridge, 1977.)

Neftel, A., J. Beer, H. Oeschger, F. Zurcher, and R.C. Finkel. 1985. Sulphate and nitrate concentrations in snow from south Greenland 1895-1978. Nature, 314(6012), 611-613.

Parkhomenko, E.I. 1967. Electrical properties of rocks. New York, Plenum Press.

Paterson, W.S.B. 1981. The physics of glaciers. Second edition. Oxford, etc., Pergamon Press.

Rahn, K.A. 1982. On the causes, characteristics and potential environmental effects of aerosol in the Arctic atmosphere. In Rey, L. and B. Stonehouse, eds. The Arctic Ocean: the hydrographic environment and the fate of pollutants. London, Macmillan, 163-195.

Rahn, K.A., E. Joranger, A. Semb, and T.J. Conway. 1980. High winter concentrations of $\mathrm{SO}_{2}$ in the Norwegian Arctic and transport from Eurasia. Nature, 287(5785), 824-826.

Semb, A., R. Brækkan, and E. Joranger. 1984. Major ions in Spitsbergen snow samples. Geophys. Res. Lett., $11(5), 445-448$.

Wolff, E.W. and R. Mulvaney. Unpublished. Further observations on the location of impurities in Antarctic ice. A paper presented at the British Branch Meeting of the International Glaciological Society, Manchester, September 1988.

Wolff, E.W. and J.G. Paren. 1984. A two-phase model of electrical conduction in polar ice sheets. J. Geophys. Res., 89(B11), 9433-9438. 